\title{
COLHENDO OS FRUTOS ESTRANHOS DA ARTE NA ERA MULTIMÍDIA
}

GARRAMUÑO, Florencia. Frutos estranhos: sobre a inespecificidade na estética contemporânea. Rio de Janeiro: Rocco, 2014

André Carlos Moraes ${ }^{*}$

Há uma linha, no âmbito das análises de estética, que faz fronteira com os estudos de Comunicação. Trata-se daquele espaço investigativo no qual as diversas modalidades de expressão, das artes plásticas à literatura, são estudadas em função de sua relação com os suportes de conteúdo, muitas vezes apontando possibilidades e até limites das diversas mídias. Consagrada com nomes como Marshall McLuhan, esta vertente inclui trabalhos recentes de autores como Hans Ulrich Gumbrecht (Atmosphere, Mood, Stimmung, de 2012). Nos últimos tempos, tem atraído interesse crescente por conta dos meios digitais. Um produto dessa linha investigativa é o conceito de Remediação, delineado por Jay David Bolter e Richard Grusin (2000), que opera, justamente, na interpenetração de mídias novas e antigas. Também há trabalhos brasileiros representativos, como Linguagens Líquidas na Era da Mobilidade (2007), em que Lucia Santaella propõe categorizações para formas expressivas emergentes a partir da análise da produção de vanguardas artísticas. É neste panorama de análises estéticas e comunicacionais que se insere o ensaio Frutos Estranhos, da argentina Florencia Garramuño. Professora da Universidade San Andres, em Buenos Aires, ela é PhD por Princeton, Estados Unidos, e pós-doutorada pela Universidade Federal do Rio de Janeiro (UFRJ). Além de garantir o interesse e as ligações com o corpo de pesquisadores brasileiros, esta experiência acadêmica continental coloca a autora em uma perspectiva ampla que favorece estudos comparativos como o desenvolvido no presente livro.

\footnotetext{
* Universidade Federal do Rio Grande do Sul, Porto Alegre, Brasil. Imeio: andrecmoraes@uol.com.br Texto Digital, Florianópolis, Santa Catarina, Brasil, v. 10, n. 2, p. AD, ago./dez. 2014. ISSNe: 1807-9288.
} 
Frutos Estranhos é, assim como faz Santaella, uma investigação de tendências culturais - e mesmo sociais - levada a cabo através da análise de vanguardas artísticas indicadoras de momentos de transformação e possibilidades exploratórias. A hipótese principal desenvolvida por Garramuño é que, em algumas das produções artísticas contemporâneas brasileiras e latinoamericanas, a deliberada corrosão de limites entre as formas de expressão, suportes e discurso, por parte dos artistas, delimita um espaço de não pertencimento que termina, justamente, criando uma identidade do inespecífico, ou seja, uma arte que se recusa a ser confinada a um único jogo de regras e enunciados possíveis, passando, assim, a ocupar novos lugares, tanto do ponto de vista estético quanto discursivo.

Na literatura, são analisados e comparados aspectos das obras de Luiz Ruffato, Tamara Kamenszain, Carlito Azevedo e Sylvia Molloy. A intensidade e abrangência do olhar da autora se evidenciam pela inclusão de nomes com projeção local costumeiramente à margem das análises totalizantes, como João Gilberto Noll. Alguns misturam a prosa com o verso, a ficção com a realidade. Nas artes plásticas, são analisados, em perspectiva, o Helio Oiticica da vanguarda brasileira dos anos 60 e, na contemporaneidade, Nuno Ramos (é uma obra dele que inspira o título do livro), que estendem o território da expressão pictórica ou escultórica para novos espaços e linguagens, da performance à instalação, criando um contínuo que promove, pela própria multiplicidade de conteúdos e intepretações, uma continuidade dialógica que inevitavelmente engloba o espectador, transformado, muitas vezes, em parte ativa do processo artístico instaurado ou provocado pelo artista/autor.

Frutos Estranhos não é apenas uma obra de crítica literária, cultural ou artística. É, em ampla medida, uma investigação sobre novas práticas expressivas ou comunicativas, nascidas em uma cultura na qual tecnologias, tradições, políticas e líricas colidem e se renovam continuamente sob os olhos do espectador/leitor/coautor. Sua principal contribuição vem deste esboço de uma 
nova categoria descritiva, a da "inespecificidade na estética contemporânea", a qual, inclusive, integra o subtítulo do ensaio.

O ponto em que é possível entrever consequências maiores do conceito proposto por Garramuño, e que inclusive justifica que se proponha esta obra como resenha de interesse para a confluência entre Comunicação e Teoria do Texto, é que este espaço identitário constituído pela implosão dos suportes e discursos tradicionais ou estanques está, precisamente, no centro de muitas das discussões sobre novas mídias e recepções. É próprio da era do texto eletrônico e da interatividade exacerbada pelas redes sociais o papel dialógico do novo leitor, transformado, muitas vezes, em agente ativo do processo, através do contato continuado, não raro ele mesmo um coautor através da apropriação ou da reconstrução/retransmissão do conteúdo. É uma extensão possível da ideia de "frutos estranhos" este equacionamento do papel ativo do leitor em face ao meio eletrônico, produzindo seu próprio conteúdo, inclusive seu próprio meio, a partir da fragmentação dos anteriores.

À parte o mérito da tese sustentada pela autora, outro ponto relevante para os interessados em desenvolver pesquisas na área vem de sua articulação acadêmica continental. Provinda do meio portenho, com passagens pelo Brasil e pelo meio universitário norte-americano, Garramuño mobiliza um repertório teórico e de referências que inclui uma importante herança do pensamento latinoamericano. Isso é válido para o corpo de textos que ela escolhe como objeto, incluindo escritores e poetas dos países vizinhos de língua espanhola, e também para as fontes eruditas, o que pode ser de utilidade para estudantes e leitores que busquem enriquecer suas revisões a partir de vertentes de pensamento situadas fora dos eixos geopolíticos que costumam preponderar nas bibliografias.

Um senão, quase externo ao trabalho em si, é uma decorrência paradoxal do mérito de Frutos Estranhos. Trazendo uma tese interessante e bem fundamentada, que pode servir como conceito operacional em estudos e projetos de investigação nas áreas de Artes, Comunicação e Teoria do Texto, o livro 
funciona principalmente como um insight, como proposição de uma categoria, mas sua análise não se estende quantitativamente. Em suas 128 páginas de formato reduzido, o volume não comporta, por exemplo, a discussão em torno de consequências mais amplas da definição proposta, ao contrário do que fazem Bolter e Grusin, em Remediation (2000). É necessário compreender que a pretensão da autora não seria tão ambiciosa e que a própria proposta da coleção "Entrecríticas", da Editora Rocco, que traz o texto ao Brasil, é, justamente, a de trazer breves intervenções teóricas para oxigenar a bibliografia disponível em português. Porém, dada a originalidade e validade da reflexão contida em Frutos Estranhos, obsta-se no sentido de que uma extensão maior poderia consolidar o modelo proposto em um construto mais amplo e, sem dúvida, de maior utilidade para a comunidade de teóricos e pesquisadores.

O ponto positivo do tamanho reduzido é que o ensaio pode ser lido facilmente, o que pode, inclusive, ajudar na disseminação de sua proposta e torná-lo uma indicação viável por parte dos professores das áreas de interesse. Esta, afinal, é uma tarefa que se impõe: refletir sobre a arte e a cultura em um contexto fortemente multimídia, em que o texto eletrônico e as novas formas de expressão produzem efeitos ainda não totalmente compreendidos. Florencia Garramuño nos ensina a colher e degustar estes frutos estranhos produzidos pelas novas mídias. Entre sabores exóticos e uma discreta, porém sedutora, toxicidade.

\section{Referências}

BOLTER, Jay David; GRUSIN, Richard. Remediation: understanding new media. Cambridge: The MIT Press, 2000.

GARRAMUÑO, Florencia. Frutos estranhos: sobre a inespecificidade na estética contemporânea. Rio de Janeiro: Rocco, 2014

GUMBRECHT, Hans Ulrich. Atmosphere, mood, Stimmung: on a hidden potential of literature. Tradução Erik Butler. Stanford: Stanford University Press, 2012. $140 \mathrm{p}$.

SANTAELLA, Lucia. Linguagens líquidas na era da mobilidade. São Paulo: Paulus, 2007. 